\title{
IMPROVING ARABIC LANGUAGE LEARNING BASED ON HIGHER ORDER THINKING SKILLS (HOTS) IN EXCELLENT SENIOR HIGH SCHOOL
}

\author{
Mokhammad Miftakhul Huda \\ Universitas Islam Negeri KH. Achmad Siddiq Jember \\ dr.hoeda@gmail.com \\ Pandi Rais \\ Institut Agama Islam Negeri Kediri \\ pandirais.10@gmail.com
}

\begin{abstract}
:
Good Arabic learning cannot be separated from the method applied. The curriculum used at MAUDU has already applied K-13, but in fact many some teachers use the classical model. Therefore, a teaching model is necessary that can bring students not only able to answer questions, but also can understand the lessons much better. They can apply the material in their daily lives, analyze and evaluate what has/have been done. This model is known as HOTS (High Order Thinking Skills). This study tries to explain the HOTS system and its relation to Arabic literacy and to innovate the development of HOTS-based materials towards innovative learning. In this study, a descriptive approach, an analytical approach, and a critical approach were used. The results achieved in this study are the innovation of developing HOTS-based Arabic learning which includes several stages, they are basic competency analysis (KD), indicator analysis, student characteristics analysis, formulating learning objectives, material analysis, developing strategies, and learning activities, developing learning tools, developing assessments, linking the principles of HOTS (High Order Thinking Skills), and Revising all aspects and steps of learning development
\end{abstract}

Keywords: Arabic Learning, HOTS, MAU DU.

\begin{abstract}
Abstrak:
Pembelajaran Babasa Arab yang baik tidak terlepas dari metode yang digunakan. Kurukulum pembelajaran yang digunakan di MAUDU sudah menggunakan K-13, akan tetapi dalam pelaksanaannya banyak yang menggunakan model klasik. Karena itu diperlukan model pengajaran yang dapat membawa siswa tidak hanya sekedar dapat menjawab pertanyaan, tetapi siswa dapat memahami dengan lebih baik, menerapkan materi dalam kesehariannnya, juga dapat menganalisis dan mengevaluasi apa yang telah dikerjakan. Model tersebut dikenal dengan HOTS (High Order Thinking Skills). Penelitian ini berusaba untuk menjelaskan system HOTS dan kaitannya dengan literasi Bahasa Arab dan membuat inovasi pengembangan materi berbasis HOTS menuju pembelajaran yang inovatif. Dalam penelitian ini, digunakan pendekatan deskriptif, pendekatan analisis, dan pendekatan kritis. Hasil yang dicapai dalam penelitian ini adalah Inovasi pengembangan pembelajaran bahasa Arab berbasis HOTS yang meliputi beberapa tahapan, yaitu analisis kompetensi dasar (KD), analisis indikator, analisis karakteristik, peserta didik, merumuskan tujuan pembelajaran, analisis materi, mengembangkan strategi, dan kegiatan pembelajaran, mengembangkan perangkat pembelajaran, mengembangkan penilaian, mengkaitkan
\end{abstract}


prinsip HOTS (High Order Thinking Skills), dan Merevisi semua aspek dan langkah pengembangan pembelajaran

Kata kunci: Pembelajaran Bahasa Arab, HOTS, MAU DU

\section{INTRODUCTION}

Along with the implementation of the 2013 curriculum, ${ }^{1}$ it is hoped that there will be a new paradigm of learning implementation in every school in Indonesia. Learning was initially teachercentered turned into student-centered, therefore, all teachers are expected to be more creative and innovative in presenting subjects. In order to test students' thinking skills, the questions used to assess student learning outcomes, especially Arabic questions, are well designed so that students are able to answer questions through thinking processes that are appropriate to operational verbs in Bloom's taxonomy. ${ }^{2}$

Arabic is a science related to many sciences, therefore the presentation of Arabic material in learning is often associated with everyday life with the aim to find concepts and develop their Arabic skills based on experience or knowledge students have.

Students must be able to solve a problem. If they are able to examine a problem and use their knowledge in particular situations. This ability is usually known as High Order Thinking Skills. High Order Thinking Skills is the ability to connect, manipulate, and change the knowledge and experience that is owned critically and creatively in determining decisions to solve problems in new situations. $^{3}$

Based on the description above, it will be examined in this study about High Order Thinking Skills in relation to Arabic literacy skills.

In practice, the application of HOTS learning is not easy to do by the teacher. Besides, the teacher must really master the material and learning strategies, the teacher is also faced with the environment and student intake challenges. Sometimes teachers feel that they are doing their best to make learning activities interesting, but students' responses are still cool, and relatively passive. Learning activities still dwell on sitting, listening, taking notes, and memorizing.

HOTS assessment instruments are questions that require higher-order thinking skills. To make the quality of students better than they were before, questions based on high-level thinking must indeed be developed by the teacher well and applied in the classroom. Higher-order thinking

\footnotetext{
${ }^{1}$ Komara Nur Ikhsan, and Supian Hadi, "Implementasi dan Pengembangan Kurikulum 2013", Jurnal Edukasi, Vol 6, No 1 (2018), p. 193

2 Kemdikbud, Modul Pelatihan Guru: Implementasi Kurikulum 2013 Mata Pelajaran Sosiologi SMA/ SMK Tahun 2014/ 2015. Jakarta: P4-BPSDM-PKPMP, Jakarta: 2014, p. 87.

3 Ahmad Muradi, Faisal Mubarak, Ridha Darmawaty, and Arif Rahman Hakim, "Higher Order Thinking Skills Dalam Kompetensi Dasar Bahasa Arab", Arabi : Journal of Arabic Studies, 5 (2), 2020, p. 181
} 
skills are divided into four groups; problem-solving, making decisions, thinking critically, and thinking creatively. ${ }^{4}$

Now, many people research about HOTS-based problems. Teachers are expected to be able to arrange HOTS questions, so students not only answer at the C-1 level (knowing), C-2 (understanding), and C-3 (applying), but also they can answer at the C-4 level (synthesis/ analysis), C-5 (evaluation), and C-6 (creative). To realize this, the K-13 developer workshop was also presented with material about making HOTS questions. The aim is to improve the quality of the questions and to make students familiar with being able to work on problems of an international standard.

HOT (High Order Thinking Skills) is a process of thinking of students in a higher cognitive level that is developed from various concepts and methods of cognitive and learning taxonomies such as the method of problem-solving, bloom taxonomy, and the taxonomy of learning, teaching, and assessment. ${ }^{5}$

According to King, high order thinking skills consist of critical, logical, reflective, metacognitive, and creative thinking. Meanwhile, according to Newman and Wehlage (Widodo, T \& Kadarwati, S. 2013), high order thinking makes students able to distinguish ideas or ideas clearly, argue well, be able to solve problems, be able to construct explanations, be able to hypothesize and be able to understand something complex becomes clear.

According to Vui, ${ }^{6}$ high order thinking skills will occur when someone connect new information with previous information stored in his memory and relate it and be able to develop that information to achieve a goal.

The researcher believes that writing HOTS-based questions is a good idea, but this should start with HOTS learning as well, because it will beweird when learning is normal, but the teacher gives HOTS questions during the exam. Thus, HOTS assessment must begin with HOTS learning.

Learning Arabic in Excellent Senior High School of Darul Ulum Step 2 has applied the 2013 Curriculum but in practice the teacher has not taught much with the HOTS method, especially Arabic subjects. Therefore, it is deemed necessary to teach Arabic with the HOTS approach, it is expected that students will not only answer at the C-1 (knowing), C-2 (understanding), and C-3 (applying) levels related to Arabic subject themes, but also students are required to develop at the level of C-4 (synthesis / analysis), C-5 (evaluation), and C-6 (creative).

\footnotetext{
${ }^{4}$ Susan M. Brookhart, How to Assess Higher Order Thinking Skills in Your Classroom. Alexandria: ASCD, 2010, p. 223225

${ }^{5}$ Hatta Saputra, Pengembangan Mutu Pendidikan Menuju Era Global: Penguatan Mutu Pembelajaran dengan Penerapan HOTS (High Order Thinking Skills). Bandung: SMILE's Publishing, 2016, p. 91.

${ }^{6}$ Dian Kurniati, Kemampuan Berpikir Tingkat Tinggi Siswa SMP Di Kabupaten Jember Dalam Menyelesaikan Soal Berstandar PISA. Penelitian dan Evaluasi Pendidikan 20(2), 2016, p. 142-155
} 


\section{LITERATURE REVIEW}

\section{Arabic learning based on HOTS (High Order Thinking Skills)}

Learning Arabic at the Excellent Senior High School of Darul Ulum Step 2 as a second language learning is essentially someone able to use a language other than the mother tongue, able to understand the language formula when listening (istima), and can apply it in speaking (takallum), reading (qira'ah) and writing (kitabab). Learning Arabic in essence is the development of social communication skills using Arabic. ${ }^{7}$

According to Thomas and Thorne, HOTS is a way of thinking that is higher than memorizing facts or applying rules, formulas and procedures. ${ }^{8}$ HOTS requires us to do things based on facts. Making linkages between facts, categorizing them, manipulating them, placing them in new contexts or ways and being able to apply them to find new solutions related to learning Arabic that are very interesting for students.

The ability to lower order thinking uses only limited abilities in routine and mechanical matters. For example memorizing and repeating information provided previously. Meanwhile, HOTS (higher order thinking) thinking ability stimulates students to interpret, analyze or even be able to manipulate previous information, so that the information conveyed is not monotonous, with HOTS based teaching models students are interested in learning and mastering Arabic. The ability of HOTS (higher order thinking) is used when someone receives new information and stores it in their memory to be used or rearranged for problem solving based on the situation faced in learning.

HOTS (Higher Order Thinking Skill) is a thinking skill that not only requires remembering skills, but requires other higher skills. Indicators for measuring the Higher Order Thinking Skill are; analysing / C4, evaluating / C5, creating / C6..$^{10}$

Brookhart (2010) describes the types of HOTS based on learning objectives in class, which consists of three categories: 1) HOTS as a transfer, 2) HOTS as critical thinking, and 3) HOTS as a problem solving. ${ }^{11}$

\footnotetext{
${ }^{7}$ Imam Asrori, Strategi Belajar Bahasa Arab Teori \& Praktek, Malang: Misykat, 2011, p. 3

${ }^{8}$ Nugroho, R Arifin, HOTS (Kemampuan Berpikir Tingkat Tinggi: Konsep, Pembelajaran, Penilaian, dan Soal-Soal, Jakarta: PT Gramedia Widiasarana Indonesia, 2018, p. 16.

${ }^{9}$ Weindy Pramita Ariandari, Mengintegrasikan Higher Order Thinking dalam Pembelajaran Creative Problem Solving. Makalah disajikan dalam Seminar Nasional Matematika dan Pendidikan Matematika UNY., 2015, p. 491

10 Aulia Mustika Ilmiani, and Delima, "Innovation In Learning Arabic Reading Skills Using Higher Order Thinking Skills", Jurnal Al-Ta'rib, Vol. 9, No. 1, June 2021, p. 103

11 Tri Widodo and Sri Kadarwati, "Problem-Solving-Based Higher Order Thinking To Improve Learning Achievement Through Students' Character Building Orientation", Cakrawala Pendidikan, Februari 2013, Th. XXXII, No. 1, p. 163
} 
So, HOTS includes the skills of analyzing, evaluating, creating, critical thinking and problem solving. Thus, HOTS provides the impact of learning for students and teachers;

a. learning will be more effective with HOT / higher order thinking,

b. improve the intellectual abilities of teachers in developing HOT / higher order thinking,

c. in this new evaluation, the teacher must always prepare questions that will not be answered simply by students.

\section{HOTS in Bloom's Taxonomy}

In the KBBI dictionary, thinking comes from the word "thought" which means reason, memory, imagination. While "thinking" means using memory to weigh and decide something. Thinking according to Kowiyah (Kowiyah, 2012), is a psychiatric process that connects events with facts, ideas or other events. In accordance with this opinion, Valentine 1965 (in Kuswana 2011) revealed that "thinking in psychological studies is to examine the process for an activity that contains about, how, which is connected with ideas directed to several expected goals". ${ }^{12}$

Students are expected to be able to process information and make the right and fast decisions in this era. Students need to develop ways of thinking and reasoning logically based on scientific facts. Benjamin Samuel Bloom is a psychologist in education who conducts research and development on thinking skills in the learning process and classifies the conceptual framework of thinking called Taxonomy Bloom. "Educational taxonomy is a framework of thinking used to clarify what we expect or interest students to find out the results of instruction". ${ }^{13}$

The dimension of thinking in Bloom's Taxonomy as perfected by Anderson \& Krathwohl (2001), consists of abilities: C1 - knowing, C2 - understanding, C3 - applying, C4 - analyzing, C5 evaluating, and C6 - creating.

The HOTS concept is explained in the discussion of cognitive domains, namely domains that involve knowledge and intellectual skills. Bloom describes the level of cognitive processes from the simplest to the complex level, known as the level of cognitive skills. Level categorization is arranged into 6 levels; (1) knowledge / C - 1; (2) comprehension / C - 2, (3) application / C - 3; (4) analysis / C - 4; (5) synthesis / C - 5; and (6) evaluation / C - 6.

The cognitive domain includes the ability of students to repeat or convey concepts that have been learned in the learning process. This process relates to the ability to think, competence in developing knowledge, recognition, understanding, conceptualization, determination and reasoning. The purpose of learning in the cognitive domain according to Bloom is all learning activities into 6 levels from lowest to highest level.

\footnotetext{
12 Wowo Sunaryo Kuswana, Taksonomi Berpikir, Bandung: Rosdakarya, 2011, p. 2

13 David R. Krathwohl, A Revision of Blom's Taxonomy: An Overview. Journa: collefe of Educarion, The Ohio State University, 2002, p. 212.
} 


\section{Learning Innovation.}

In learning Arabic, the teacher must constantly develop learning innovations that can improve students' thinking skills to a higher level of understanding and interest of students towards Arabic lessons, so that problems related to the HOTS model in Arabic subjects can be solved.

In general, teachers in Senior High School still lack innovation in developing Arabic learning, especially HOTS-based learning, so students often encounter difficulties when facing problems that require higher-level thinking, such as in Arabic competitions. This problem also occurs in Excellent Senior High School of Darul Ulum Step 2.

This research activity is expected to provide the following benefits:

1. The teachers have insight into innovative Arabic learning based on HOTS.

2. The competence and professionalism of Arabic teachers increases in relation to innovative learning.

3. Arabic language teachers are able to explore and develop the potential of their students to improve Arabic learning achievement, through innovative Arabic learning based on HOTS. Effective learning strategies will help students towards higher-level thinking skills (HOT). Learning steps that can improve students' way of thinking as explained by Given: ${ }^{14}$

1. Students write the learning achievements to be achieved that day (Emotional Learning),

2. Do a Brain Gym while learning (Physical Learning),

3. directing the use of concepts in everyday life (Emotional Learning),

4. discuss a problem.

The development of the HOTS model in Arabic requires a variety of criteria both questions and subject matter content. There are several ways that can be used as a guide by teachers in writing questions that require students to think at a higher level. The questions to be asked are measured by behavior in accordance with Bloom's cognitive domain at the level of analysis, evaluation and creation, each question is given a basic question (stimulus). The HOTS question should minimize the ability to recall information, but rather measure the ability. The question development technique is based on the principle of higher order thinking skills including:

1. Creativity Thinking and Innovation

2. Critical Thinking and Problem Solving

3. Communication

4. Collaboration

${ }_{14}$ Achmad Fanani, and Dian Kusmaharti, "Pengembangan Pembelajaran Berbasis Hots (Higher Order Thinking Skill) Di Sekolah Dasar Kelas V", JPD: Jurnal Pendidikan Dasar, Vol 9 No 1 (2018), p. 4 


\section{METHOD}

To facilitate the researchers in this study, the researchers used several approaches that were appropriate for their research. The approaches are descriptive approaches, analytical approaches, and critical approaches.

Descriptive approach, describing learning Arabic in The Excellent Senior High School of Darul Ulum Step 2. The analytical approach, analyzing improving the quality of curriculum and learning Arabic in the Excellent Senior High School of Darul Ulum Step 2 towards the development of effective language learning. Meanwhile, the critical approach consists of intensifying curriculum development and learning Arabic in the Excellent Senior High School of Darul Ulum Step 2.

This research is descriptive quantitative research. This research aims to explain the phenomena that exist by using numbers to describe the characteristics of individuals or groups. This study assesses the nature of the conditions that appear. The purpose of this study is limited to describe the characteristics of things as they are. This research also involved the participants. Participants are people who are interviewed, observed, asked to provide data, opinions, thoughts, perceptions. Information collected through in-depth interviews with informants (head masters and teachers). The process of observation and in-depth interviews is very important in data collection. From this observation it is expected to be able to explore innovative curriculum management and learning Arabic at the Excellent Senior High School of Darul Ulum Step 2.

Data collection techniques using observation, interviews, and documentation. Based on this concept, the three data collection techniques above were used in this study; 1) interviewee, ${ }^{15}$ 2) observation, ${ }^{16} 3$ ) documentation. ${ }^{17}$

\section{RESULTS AND DISCUSSION}

One of the changes to the 2013 curriculum in schools is to strengthen the learning process. Through strengthening of the learning process, it is hoped that it can improve the quality of learning more effectively, efficiently, fun, and meaningfully. So as to improve the achievement of learning outcomes and make students think critically (not just convey factual). In fact, there are still many

\footnotetext{
15 Sugiyono, Metode Penelitian Tindakan Komprehensif (Bandung: Alfabeta, 2015), 267. Haris Herdiansyah, Wawancara Observasi dan Focus Groups (Jakarta: PT Raja Grafindo Persada, 2015), p. 31; M. Miftakhul Huda, Affan Nur Habib, Risna Zamzamy, and Majidatul Muyasaroh, "Problematika Mahasiswi Program Tahfidz Al-Qur'an di Ma'had Darul Hikmah Iain Kediri", Jurnal UMSIDA, Vol 2, No 2 (2018), p. 221

${ }^{16}$ Haris Herdiansyah, Wawancara Observasi dan Focus Groups (Jakarta: PT Raja Grafindo Persada, 2015), p. 31.

17 Djam $^{e e}$ an Satori and Aan Komariah, Metodologi Penelitian Kualitatif (Bandung: Alfabeta, 2009), p. 11; Suci Arischa, Zulkarnain, "Analisis Beban Kerja Bidang Pengelolaan Sampah Dinas Lingkungan Hidup Dan Kebersihan Kota Pekanbaru”, JOM FISIP Vol. 6: Edisi I Januari - Juni 2019, p. 8
} 
teachers who do not understand about HOTS (High Order Thinking Skills). This is evident in the formulation of indicators, objectives, and learning and assessment activities.

Teachers must be able to develop and convert from Lower Order Thinking Skills (LOTS) to Higher Order Thinking Skills HOTS (High Order Thinking Skills) and this must have been initiated since designing the Learning Implementation Plan (RPP).

Learning to design a Learning Implementation Plan (RPP) is an attempted by someone to achieve a goal, the effort is to steer someone from a state that cannot be able to, and from not knowing to knowing that is influenced by internal and external factors.

The next stage after completing the learning implementation of lesson plans (RPP) is to apply in learning activities. Learning is a system or process of learning students that are designed, implemented, and evaluated systematically so that students can achieve the expected learning goals. Learning has several components, including learning objectives, learning materials, learning strategies and methods, learning media, and evaluation of learning. So learning is processing something to produce the desired output.

The research data was obtained through interviews, observations, documentation, and tests. Interviews were conducted with teachers and 21 students of class XI AGT 1 to get an overview of students' understanding before and after the implementation of the HOTS (High Order Thinking Skills) learning model. In addition to interviews researchers also conducted observations.

The observation is to observe the activities of students and teachers when applying the HOTS (High Order Thinking Skills) Learning model. While the documentation, the data of students in class XI AGT 1 at Excellent Senior High School of Darul Ulum Step 2 as well as Arabic evaluation value data related to the title of the Month of Ramadan. Finally, the researcher evaluates at the end of the study.

From the results of interviews of Arabic language teachers and students in class XI AGT 1 Excellent Senior High School of Darul Ulum Step 2 and supported by student value documents provided by the teacher to the researcher.

This interview was conducted on Wednesday, June1 $2^{\text {th }}, 2019$ at 09.30 a.m. This interview was conducted to determine the condition of students' understanding of the learning model used and the results of the evaluation at the end of Arabic learning.

The interviews show that teachers use direct learning method in teaching Arabic in clas. Teachers more often convey learning by lecturing in front of students, reading material, and giving assignments. So that learning is centered on the teacher, the teacher is more active than the students. This causes many students to be sleepy, daydream themselves, often get permission to go to the bathroom, disturb their friends, and are less enthusiastic about participating in class learning. 
In addition, students tend to be passive and do not dare to express their opinions or ask questions when it is difficult to understand Arabic. These difficulties cause the low ability of students to understand Arabic material. This can be seen from the results of students' exams.

The development of HOTS (High Order Thinking Skills) towards the development of innovative learning

Based on the background of the study, it can be identified the problem of learning Arabic in the Excellent Senior High School of Darul Ulum Step 2 so that it can be formulated an innovative Arabic learning problem based on HOTS (High Order Thinking Skills) in the Excellent Senior High School of Darul Ulum Step 2.

The solution offered to solve the problem is through FGD (Focus Group Discussion) to strengthen the insight of innovative Arabic learning, followed by workshops to develop a plan and learning media, and at the end of the activity held the practice of implementing innovative Arabic learning based on HOTS ( High Order Thinking Skills.

The approach and method used in completing this activity is Focused Discussion / FGD. Focused Discussion (FGD) was held to strengthen the insights of innovative Arabic learning and the preparation of learning plans, where at this stage the research team presented something as the focus of the discussion material. Then there will be discussion and question and answer session, where participants will discuss HOTS (High Order Thinking Skills) learning theories and innovative learning plans based on HOTS (High Order Thinking Skills) and are equipped with effective learning media.

\section{RESEARCH ACTIVITIES}

The study began on Saturday, June $1^{\text {st }}, 2019$ until Monday, September 30 $0^{\text {th }}, 2019$ at the Madrasah Aliyah Unggulan Darul Ulum which was attended by 9 Arabic teachers and 2 researchers.

In this study, researchers developed Arabic questions based on HOTS. The Arabic questions can be classified into four parts, namely: Listening (Istima'), Writing (Kitabah), Reading (Qiro'ah) and Speaking (Kalam).

FGD activities continued with discussion, question and answer. Enthusiastic participants gave responses about HOTS (High Order Thinking Skills) followed by questions and answers about developing HOTS (High Order Thinking Skills) questions.

The next phase of the activity is focused on innovative learning planning based on HOTS (High Order Thinking Skills). This activity also begins with the presentation of material on the preparation of learning plans (RPP). 
Learning planning material based on HOTS (High Order Thinking Skills) is also an interesting topic. This can be seen from the participants' enthusiasm during the question-and-answer session, including asking about operational words on the indicators that lead to HOTS (High Order Thinking Skills).

\section{Research Evaluation Results (Pretest and Posttest)}

The analysis output is divided into three tables. The first table contains descriptive statistics, the second table contains correlations between pre-test and post-test, and the third table contains statistical analysis with SPSS $21 .^{18}$

\section{Descriptive Statistics: Table Paired Samples Statistics}

The Paired Samples Statistics table shows some descriptive values of each variable in the paired sample.

a. Pre-test has an average value (mean) of 68.86 out of 21 students used as research samples.

The data distribution (Std. Deviation) obtained was 6,966 with a standard error of 1,520.

b. Post test has an average value (mean) of 81.95 out of 21 students used as research samples.

Data distribution (Std. Deviation) obtained 3,008 with a standard error of 0.656.

Because the average value of learning outcomes in the Pre Test $68.86<$ Post Test 81.95 , then it means some differences in the average learning outcomes between the Pre Test and the Post Test results. Furthermore, to prove whether the differences are real or not, it is necessary to interpret the results of the paired sample $t$ test contained in the "Paired Samples Test" output table.

This shows the final test on the data is higher than the pre test. However, the range of post test data distribution also becomes wider and with higher standard errors.

\section{Descriptive Statistics: Table Paired Samples Correlations}

Paired Samples Correlations table shows the correlation of the relationship between the two variables in the paired sample. The output above shows the correlation test results or the relationship between the two data or the relationship of the Pre Test variable with the Post Test variable. Based on these outputs it is known that the correlation coefficient is 0.651 with a significance value (Sig.) Of 0.001 . Because the value of Sig. $0.001<$ probability 0.05 , it can be said that there is a relationship between the Pre Test variable and the Post Test variable.

\section{Descriptive Statistics: Table Paired Samples Correlations}

The third output is the most important output, because in this part we will find the answers to the questions in the case above, namely the influence of the use of the HOT method on learning outcomes in Arabic subjects in class XI AGT 1 in academic 2019.

\footnotetext{
18 Jono Irawan, Ayu Trisna Handayani, and Lalu Hasan Nasirudin Zohri, "Operasionalisasi IBM SPSS 21 untuk Meningkatkan Kemampuan dan Keterampilan Olah Data Penelitian Mahasiswa", Jurnal Pengabdian Magister Pendidikan IPA, Vol 4 No 2 (2021), p. 69.
} 
Before discussing the interpretation of the numbers contained in the "Paired Samples Test" output table above, it is first necessary to know the research hypothesis formulation and decisionmaking guidelines in paired sample $t$ test.

Paired Samples Test table is the main table of output that shows the results of tests conducted by researchers. This can be seen from the significance value (2-tailed) in the table.

Research Hypothesis Formulation:

a. Ho $=$ There is no average difference between Pre Test and Post Test learning outcomes, which means that there is no influence on the use of HOT model learning strategies in improving learning outcomes for Arabic subjects in class XI AGT 1 academic year $2019 / 2020$.

b. $\mathrm{Ha}=$ There is an average difference between the Pre Test and Post Test learning outcomes, which means that there is an influence on the use of the HOT learning model in improving learning outcomes for Arabic subjects in class XI AGT 1 academic year 2019/2020.

According to Singgih Santoso, the guidelines for decision making in the paired sample t-test based on the significance value (Sig.) Of the SPSS output are as follows::

a. If the Sig. $(2$ - tailed $)<0.05$, then $\mathrm{Ho}$ is rejected and $\mathrm{Ha}$ is accepted.

b. Opposite of point a, if the value of Sig. (2-tailed) $>0.05$, then Ho is accepted and Ha is rejected.

Based on the "Paired Samples Test" output table above, we know the Sig. (2-tailed) is 0.000 $<0.05$, then $\mathrm{Ho}$ is rejected and $\mathrm{Ha}$ is accepted. So, it can be concluded that there is an average difference between Pre Test and Post Test which means that there is an influence on the use of HOT model learning strategies in improving learning outcomes for Arabic subjects in class XI AGT 1 academic year 2019/2010.

From the output table "Paired Samples Test" above also contains information about the value of "Mean Paired Differences" of 13,095. This value shows the difference between the average Pre Test learning outcomes with the Post Test average learning outcomes or $68.8681 .95=13,095$ and the difference between 15,600 to 10,590 (95\% Confidence Interval of the Difference Lower and Upper).

The significance value $(2$-tailed) from this case sample is $0,000(p<0.05)$. So the results of the pre-test and post-test have significant changes (meaning). Based on descriptive statistics the post test value is higher. It can be concluded that learning by using HOT can increase the creativity of students in answering questions. 
Improving Arabic Language Learning Based On Higher Order Thinking Skills.......

\section{CONCLUSION}

From the observations during the course of this research activity, it can be concluded that this activity is very beneficial for the Excellent Senior High School of Darul Ulum Step 2, as follows;

The innovation development of Arabic learning based on HOTS (High Order Thinking Skills) developed in this study includes several stages, they are Basic Competency Analysis (KD), Indicator Analysis, Analysis of student characteristics, Formulating learning objectives, Material analysis, Developing strategies, and activities learning, developing learning tools, Developing assessments, Linking the principles of HOTS (High Order Thinking Skills), and Revising all aspects and steps of learning development.

The results of the development of Arabic learning innovations in MA Darul Ulum by using the HOT Prototype model developed in this study in the form of learning device products that include lesson plans, teaching materials, and assessment of learning based on HOTS (High Order Thinking Skills).

\section{REFERENCES}

Ariandari, Weindy Pramita, Mengintegrasikan Higher Order Thinking dalam Pembelajaran Creative Problem Solving. Makalah disajikan dalam Seminar Nasional Matematika dan Pendidikan Matematika UNY, 2015.

Asrori, Imam, Strategi Belajar Bahasa Arab Teori \& Praktek, Malang: Misykat, 2011.

Brookhart, Susan M., How to Assess Higher Order Thinking Skills in Your Classroom. Alexandria: ASCD, 2010.

Herdiansyah, Haris, Wawancara Observasi dan Focus Groups (Jakarta: PT Raja Grafindo Persada, 2015). Kemdikbud, Modul Pelatiban Guru: Implementasi Kurikulum 2013 Mata Pelajaran Sosiologi SMA/ SMK Tabun 2014/ 2015. Jakarta: P4-BPSDM-PKPMP, Jakarta: 2014. 
Krathwohl, David R., A Revision of Blom's Taxonomy: An Overview. Journa: collefe of Educarion, The Ohio State University. 2002

Kurniati, Dian, Kemampuan Berpikir Tingkat Tinggi Siswa SMP Di Kabupaten Jember Dalam Menyelesaikan Soal Berstandar PISA. Penelitian dan Evaluasi Pendidikan 20(2), 2016.

Kuswana, Wowo Sunaryo. Taksonomi Berpikir. Bandung: Rosdakarya, 2011.

Nugroho, R Arifin. 2018. HOTS (Kemampuan Berpikir Tingkat Tinggi: Konsep, Pembelajaran, Penilaian, dan Soal-Soal). Jakarta: PT Gramedia Widiasarana Indonesia.

Saputra, Hatta, Pengembangan Mutu Pendidikan Menuju Era Global: Penguatan Mutu Pembelajaran dengan Penerapan HOTS (High Order Thinking Skills). Bandung: SMILE’s Publishing, 2016.

Fanani, Achmad and Dian Kusmaharti, "Pengembangan Pembelajaran Berbasis Hots (Higher Order Thinking Skill) Di Sekolah Dasar Kelas V", JPD: Jurnal Pendidikan Dasar, Vol 9 No 1 (2018).

Huda, M. Miftakhul, Affan Nur Habib, Risna Zamzamy and Majidatul Muyasaroh, "Problematika Mahasiswi Program Tahfidz Al-Qur'an di Ma’had Darul Hikmah IAIN Kediri", Jurnal UM-SIDA, Vol 2, No 2 (2018).

Ilmiani, Aulia Mustika and Delima, "Innovation In Learning Arabic Reading Skills Using Higher Order Thinking Skills", Jurnal Al-Ta'rib, Vol. 9, No. 1, June 2021.

Irawan, Jono, Ayu Trisna Handayani and Lalu Hasan Nasirudin Zohri, "Operasionalisasi IBM SPSS 21 untuk Meningkatkan Kemampuan dan Keterampilan Olah Data Penelitian Mahasiswa", Jurnal Pengabdian Magister Pendidikan IPA, Vol 4 No 2 (2021).

Muradi, Ahmad, Faisal Mubarak, Ridha Darmawaty, and Arif Rahman Hakim, "Higher Order Thinking Skills Dalam Kompetensi Dasar Bahasa Arab", Arabi : Journal of Arabic Studies, $5(2), 2020$ 
Improving Arabic Language Learning Based On Higher Order Thinking Skills.......

Satori, Djamee an and Aan Komariah, Metodologi Penelitian Kualitatif (Bandung: Alfabeta, 2009), 11; Suci Arischa, Zulkarnain, “Analisis Beban Kerja Bidang Pengelolaan Sampah Dinas Lingkungan Hidup Dan Kebersihan Kota Pekanbaru", JOM FISIP Vol. 6: Edisi I Januari - Juni 2019.

Sugiyono, Metode Penelitian Tindakan Komprehensif (Bandung: Alfabeta, 2015), 267. Haris Herdiansyah, Wawancara Observasi dan Focus Groups (Jakarta: PT Raja Grafindo Persada, 2015).

Widodo, Tri and Sri Kadarwati, "Problem-Solving-Based Higher Order Thinking To Improve Learning Achievement Through Students' Character Building Orientation", Cakrawala Pendidikan, Februari 2013, Th. XXXII, No. 1. 